\title{
ETHIOPIAN RIFT AND PLATEAUS: SOME VOLCANIC PETROCHEMICAL DIFFERENCES
}

\author{
P. A. Mohr
}

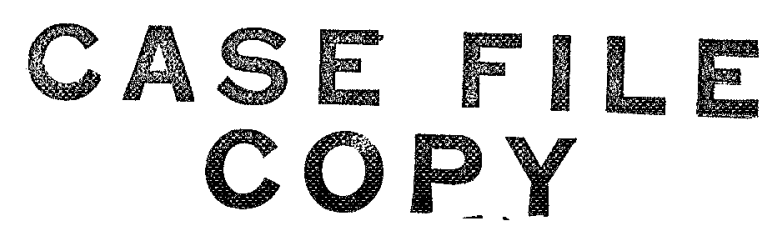

March 1970

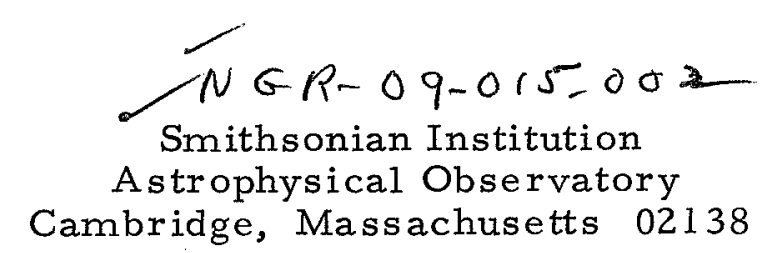


Ethiopian Rift and Plateaus: Some Volcanic Petrochemical Differences

P. A. MOHR

Smithsonian Astrophysical Observatory, Cambridge, Massachusetts 02138

Ethiopian volcanism has been strictly controlled in space and time by the development of the Ethiopian swell and its traversing rift-valley system. Contemporaneous volcanism in the rift and on the plateaus shows some interesting differences. The plateau basalts tend to be more undersaturated than do the rift basalts, although minor occurrences of tholeiite are restricted to the plateaus. Peralkaline intermediate lavas, usually strongly undersaturated, form notable associations on the plateaus, but in the rift they are subordinate to silicic lavas and are definitely more calcic. The plateau silicic lavas have comenditic affinity, whereas those of the rift have pantelleritic affinity. Although these distinctions are usually transitional rather than abrupt, they point to fundamental differences in magma genesis under the volcanic rift floor and under the sialic plateau.

\section{INTRODUCTION}

The Cainozoic volcanics of Ethiopia and Yemen were erupted during development of the Arabo-Ethiopian swell and its traversing rift valleys. They form what is perhaps the world's largest alkaline volcanic province, though calc-alkaline lavas (e.g., tholeiitic basalts) are not unknown. The province is notably situated on a triple junction of the world ridge-rift system, where the Gulf of Aden, Red Sea, and African rift structures converge at Afar (Figure 1).

Oceanographic data strongly imply a Cainozoic drift of Arabia northeastward from Africa [Laughton, 1966; Tramontini and Davies, 1969], with the floors of the Gulf of Aden and Red Sea being composed of young oceanic crust 
generated by typical tholeiitic magmatism [Schilling, 1969], contrasting with the thick sialic crust of the continental plates [Niazi, 1968]. However, the occurrence of Afar and its bordering sialic horsts within the triple junction is an unexplained paradox in the simple theory of plate separation of Arabia from Africa.

Some workers have considered Afar to be merely subsided sialic crust once contiguous with the bordering Ethiopian and Somalian plateaus [e. g. , Gortani, 1950]. More recently, the concept that the Afar depression represents exposed oceanic crust has become widely accepted because it fits with the oceanographic data [Bullard, 1969]. Other workers point to the problem of the existence of the Danakil and Aisha horsts within the triple junction, and the implications from structural geology that fragmented blocks of sialic crust form an appreciable proportion of the Afar floor under the cover of young lavas and sediments [Mohr, 1967; Gass and Gibson, 1969] .

As a contribution toward resolving this controversial problem, an attempt is made here to examine and contrast the volcanic chemistry of the plateau and rift subprovinces of the Ethiopian region. Any chemical distinctions can then be discussed in terms of presumed differences in crustal and subcrustal nature of the two subprovinces, though a major handicap remains our lack of understanding of the petrogenesis of silicic magma in a rift environment [Sigurdsson, 1967; McBirney, 1969]. Molly [1934] attempted to find a petrographic basis for distinction between the older (plateau) and younger ( $r$ ift) lavas of Ethiopia, with ambiguous success.

\section{AGE AND DISTRIBUTION OF THE ETHIOPIAN VOLCANICS}

These topics have been discussed in some detail elsewhere [Mohr, 1963, 1968]. The sequence of major vulcanism can be summarized as follows (Figure 2): 
4. Aden Series

3. Afar Series

2. Shield Group

1. Trap Series (c) Fissure basalts and caldera silicics in rift. Rare basaltic cinder-cone activity on plateau (Upper Pleistocene-Holocene).

(b) Basalts, tephrites, phonolites on the plateaus, especially in the Tana $r$ ift. Minor basaltic and strong silicic volcanism in main Ethiopian $r$ ift and Afar (Middle Pleistocene).

(a) Extensive pantelleritic ignimbrites in southcentral Ethiopia, and possibly contemporaneous silicics in Afar. Peralkaline intermediate lavas of restricted extent on the plateaus. Rather minor basalt and nephelinitic activity, particularly on the Somalian plateau (Plioceneearly Pleistocene).

Flood basalts and mugearitic derivatives, with minor end-phase silicic volcanism, in central and eastern Afar (late Miocene?-Pliocene).

Central-type flood alkali olivine basalts and hawaiites on plateaus. Occasional end-phase comenditic lavas and stocks. Abundant minor intrusive activity, with dike swarms of both basaltic and silicic composition (Lower MiocenePliocene).

Fissure flood basalts forming a very extensive cover on the Arabo-Ethiopian swell. Alkali olivine basalts predominate. Some intraformational unconformities are too localized to be used for subdividing this thick series on a regional basis. Silicic lavas very rare. The Trap Series plunges under the margins of the present rift floor, but its extent under Afar is debatable (Eocene-Oligocene). 
The rift grabens were not in existence until the Plio-Pleistocene. Before then the rifts were sites of troughs formed by crustal downwarping [Baker and Mohr, 1970]. Afar is distinct from the true rift valleys in that its tectonic development commenced earlier, in the Mesozoic, with major boundary faulting accompanying the Miocene phase of swell uplift. The Tana rift, containing Lake Tana, is wholly within the Ethiopian plateau (Figure 1): its volcanics are included with plateau volcanics in this study, though some specific features are discussed. It must be emphasized that the re are many local variations on the general succession given above and that these can influence interpretation of plateau-rift volcanic chemistry. Some of the more important variations are brought out in the discussion, but their full significance cannot be realized until many more data are available.

\section{CHEMISTRY}

Nature of the Ethio-Yemen volcanics. The alkaline nature of the EthioYemen volcanics has long been recognized [Manasse, 1909; Raisin, 1903; Weber, 1906; Roman, 1926], and comparisons effected with the volcanics of the East African rift system farther south [ 1955]. The recent success of the hypothesis of sea-floor spreading and an awareness of the role of oceanic rifts in crustal-plate tectonics naturally lead to a reexamination of all available data on the Ethio-Yemen volcanics in relation to their tectonic setting: for example, an examination of the basalts of the axial zone of the rifts for tholeiitic tendencies. Again, McBirney and Gass. [1967] have demonstrated a pattern of chemical variation of oceanic-island silicic lavas according to their position of extrusion on the mid-oceanic ridges. The Ethiopian and Kenyan swells could be considered analogous to oceanic ridges [Baker and Mohr, 1970], and their silicic lavas thus reexamined from this aspect.

The chemical data for this paper are based on the new collection of all published Ethiopian and Yemeni rock analyses and petrographic descriptions [Mohr, 1970a]. Table 1 lists average compositions for five major lava classes, with standard deviations for each oxide. The classification of 
individual rocks has been according to limiting oxide parameters as follows: for "alkaline basalts, " $\mathrm{SiO}_{2}<50 \%, \mathrm{MgO}<10 \%, \mathrm{CaO}<14 \%$, and $\mathrm{Na}_{2} \mathrm{O}+\mathrm{K}_{2} \mathrm{O}>3 \%$; for "subalkaline basalts, " $47 \%<\mathrm{SiO}_{2}<53 \%, \mathrm{CaO}<14 \%$, arid $\mathrm{Na}_{2} \mathrm{O}+\mathrm{K}_{2} \mathrm{O}<3 \%$; for "intermediate volcanics," $55 \%<\mathrm{SiO}_{2}<67 \%$; for "sodic rhyolites, " $\mathrm{SiO}_{2}>67 \%$ and $\mathrm{Na}_{2} \mathrm{O}>\mathrm{K}_{2} \mathrm{O}$; and for "potassic rhyolites," $\mathrm{SiO}_{2}>67 \%$ and $\mathrm{Na}_{2} \mathrm{O}<\mathrm{K}_{2} \mathrm{O}$.

This method of crude classification is certainly not ideal but is necesitated by the lack or paucity of petrographic description for many of the published rock analyses. In particular, the distinction made here between alkaline and subalkaline basalt is arbitrarily based on Yoder and Tilley's [1962] boundary condition for alkali basalt-tholeiite of $3 \%$ total alkalis; in fact, a recently described olivine tholeiite from the Ethiopian plateau contains more than this amount [LeBas and Mohr, 1970]. Nevertheless, the essential nature of the Ethio-Yemen volcanism is brought out, and its alkaline nature emphasized in comparison with other continental flood-basalt occurrences. For such a comparison, the reader is referred to Mohr [1963].

Figure 3 shows the $\mathrm{SiO}_{2}$ histogram for the Ethio-Yemen volcanics. While it is considered to give a reasonably accurate picture of abundant and deficient $\mathrm{SiO}_{2}$ percentages, it is important to know that basalts are volumetrically six times as abundant as silicics in Ethiopia [Mohr, 1968]. This is indicative of the well-known fact that the silicic lavas have received disproportionate attention compared with the monotonously extensive flood basalts. A relative lack of intermediate lavas in the $51-58 \% \mathrm{SiO}_{2}$ range is evident, and an intermediate "gap" for the lavas of the Erta-ali volcanic chain of northern Afar has been pointed out by Tazieff et al. [1970] as raising some acute petrogenetic problems. A similar silica distribution pattern holds for the East African volcanic province [Wright, 1965], though Williams [1969] considers that the deficiency of intermediate lavas there has been overemphasized. 


\section{METHODS AND LIMITATIONS OF CHEMICAL COMPARISONS}

Before a comparison is made between plateau and rift volcanic chemistry, the limitations of the methods used must be realized. Excluded from the data presented in Tables 2 and 3 are all rock analyses with $\mathrm{MnO}>1.5 \%$, $\mathrm{MgO}>10 \%, \mathrm{CaO}>14 \%$ (i. e., accumulates and also some suspect analyses). Then all analyses with $\mathrm{SiO}_{2}<51 \%$ have been included under "basalts, " rocks with $54 \%<\mathrm{SiO}_{2}<65 \%$ under "intermediates," and rocks with $\mathrm{SiO}_{2}>67.5 \%$ under "silicics." McBirney [1969] has pointed out the dangers of classifying rocks on a purely chemical basis, without consideration of field occurrence and associations. Unfortunately, such is the present state of Ethiopian and Yemeni volcanology that the positions and interrelationships of analyzed specimens remain very poorly known [as an example, see Comucci, 1950]. The bounding parameters given above are based on Figure 3 and on generally accepted ranges in composition of common rock types.

A second limitation on the value of the chemical data stems from unrepresentative sampling. Some regions have received a relatively intensive study, whereas data on others, particularly in southern Ethiopia, are almost completely lacking. To try to remedy this by use of single averages for well-sampled regions would involve further arbitrary decisions on where to draw the boundaries of the particular region and how to weight the average where there is a fractionation series. Though this problem is still being reviewed, it is considered best to treat all raw data on an equal basis and with a method that will apply well when the large number of new analyses representing the whole region is available in the near future.

Finally, Tables 2 and 3 show that the standard deviations about individual oxide values are large enough that there are few statistically significant differences between plateau and rift volcanics in any class. This lack of statistical significance is considered to be unreal for the following reasons. First, the range of $\mathrm{SiO}_{2}$ values within any class means that the other oxides can be expected to vary at least over their corresponding fractionation 
ranges. A solution to this problem would be to compute a standard $\mathrm{SiO}_{2}$ value for each class and adjust the other oxides according to individual deviations of $\mathrm{SiO}_{2}$ from the standard value. But this involves assumptions on the possible fractionation trends and petrogenesis of the Ethiopian volcanics, which are precisely the topics under dispute [compare Barberi et al. , 1970; Harkin, 1960; Wright, 1965; Saggerson and Williams, 1964]. Second, there are some marked regional variations within the plateau and rift subprovinces: for example, the Fant-ali volcanics show a degree of $\mathrm{Na}-\mathrm{Fe}$ enrichment and Al depletion that is unlikely to be typical of the main Ethiopian rift as a whole; and the Jimma pantelleritic ignimbrites are untypical of the Ethiopian plateau silicics as a whole. Nevertheless, while these factors increase the standard deviations and thus preclude the use of discriminants for classifying individual analyses, it is considered that they should not detract from some consistent differences that are present between all classes of plateau and rift volcanics, both in Ethiopia and in Yemen. This consistency was noted, on the basis of fewer data, by Mohr [1963].

The placement of individual analyses in either the plateau or the rift category has been based on the best available structural maps. For the main Ethiopian rift, the major graben faulting provides a clear boundary between young plateau and rift volcanism, though for pre-graben volcanics the distinction is more obscure. For Afar, the inner structural margin of Mohr [1967] has been chosen as the boundary, and thus lavas within the downwarped region between the inner and the outer structural margins are included with the plateau. Lavas of the Danakil and Aisha horsts are currently included with rift volcanics, excepting the southern portion of the sialic Aisha horst, where it is contiguous with the Somalian plateau. This treatment of the Afar horsts can be reconsidered when more analyses are available, though existing data reveal a character that is intermediate between rift and plateau and that even in some instances tends to plateau-type chemistry. Volcanics of the Tana rift, within the Ethiopian plateau, are considered to belong to the plateau if only because of the small size and sialic foundation of this interesting rift [Mohr and Rogers, 1966; Mohr, $1970 \mathrm{~b}]$. The boundaries between plateau and $r$ ift in Yemen have proved 
more difficult to delineate, and the volcanics of the Aden coast have been considered as rift volcanics despite the overlap of at least one center onto Trap Series lavas [Gass and Mallick, 1968].

\section{DISCUSSION}

The data suggest that, both in Ethiopia and in Yemen, the rift volcanics compare with the plateau volcanics as follows:

1. The rift basalts may have higher $\mathrm{Si}, \mathrm{Fe}, \mathrm{Ca}$, and $\mathrm{Na} / \mathrm{K}$ and lower $\mathrm{Al}, \mathrm{K}$, and $\mathrm{Mg} / \mathrm{Fe}$.

2. The rift intermediates may have higher $\mathrm{Fe}, \mathrm{Mg}, \mathrm{Ca}, \mathrm{Na} / \mathrm{K}, \mathrm{Mg} / \mathrm{Fe}$, $\mathrm{Ti}$, and $\mathrm{P}$ and lower $\mathrm{Al}, \mathrm{Na}, \mathrm{K}$, and $\mathrm{Fe}^{3} / \mathrm{Fe}^{2}$.

3. The rift silicics may have higher $\mathrm{Na}$ and $\mathrm{Na} / \mathrm{K}$ and lowe $\mathrm{Fe} \mathrm{e}^{3} / \mathrm{Fe}^{2}$.

Some of these distinctions are common to more than one class: for example, $\mathrm{Na} / \mathrm{K}$ is higher in the rift volcanics of all three classes, though for reasons discussed below it is unlikely that there is only one cause.

Basalts. The $r$ ift basalts show a distinctly tholeiitic tendency compared with the plateau basalts. This is emphasized in the norms, where the rift basalts are quartz normative and the plateau basalts nepheline normative. While there are localized occurrences of true tholeiites on both the Ethiopian and the Somalian plateaus, it is in northern Afar that olivine-rich basalts with tholeiitic tendencies are particularly abundant [Tazieff and Varet, 1969; Barberi et al., 1970]. These young basalts of Afar have been extruded from en-echelon volcanic alignments paralleling the Red Sea and are considered by Tazieff and Varet [1969] to be of oceanic type in a region lacking sialic crust. Quaternary basalts are much less voluminous in central and southern Afar and in the main Ethiopian rift, where they are also more alkaline.

An important distinction between plateau and rift volcanism in Ethiopia is the restriction of feldspathoid-bearing lavas to the plateau environment [Le Bas and Mohr, 1968]. This distinction appears, though less clear cut, between rift and plateaus in the even more alkaline Kenyan volcanic province 
[Wright, 1965]. The alkaline character of the Yemeni plateau basalts is less marked than that in Ethiopia, in conformity with the pattern of increasing alkalinity southward along the African rift system [Harris, 1967; Mohr, 1963 , 1968]. Harris relates this pattern to increasing depth of melting southward and thus to a steeper thermal gradient under the Red Sea (characterized by oceanic-type tholeiites [Schilling, 1969]) than under eastern Africa. It will be interesting to test this plausible hypothesis, which relates the degree of swell uplift and crustal distension to heat flow, with seismic refraction studies now in progress.

The tholeiitic character of the Ethiopian $r$ ift basalts compared with the plateau basalts invites comparison with other flood-basalt as sociations on the world ridge-rift system. McBirney and Gass [1 967] have suggested, from their study of a compendium of Pacific and Atlantic ridge lavas, that the more undersaturated lavas emerge on the flanks of the ridges, and the more saturated lavas in or close to the median rift. Detailed study of a section of the mid-Atlantic $r$ ift shows a relatively rapid transition from tholeiites on the rift floor to alkali basalts on the hills overlooking the rift [Aumento, 1967, 1968]. The chemical pattern of the Ethiopian basalts therefore appears to be analogous to oceanic ridge-rift basalts in general, despite the presence of sialic crust forming the Ethio-Yemen plateaus.

Gass [1970] considers that the relation of alkali basalts to tholeiites in the Ethio-Yemen regions is largely a temporal one: "alkali basalts were erupted during the early period when vertical [swell] uplift was dominant... whereas the 'oceanic' crust in the Red Sea, Gulf of Aden and Afar Depression, formed during the lateral movement of sialic blocks in the late Tertiary, is of tholeiitic character." However, this does not present a valid picture of the tectonic evolution of the Ethiopian region. Swell uplift has been operating during periods of varying intensity all through the Cainozoic, and likewise, distensional crustal movements are probably longstanding despite the late replacement of rift troughs by graben [Mohr, 1967]. Furthermore, the Quaternary basalts of the plateaus remain strongly alkaline. It might be considered more accurate to state that tholeiitic 
basalts are associated with lines of crustal thinning, regardless of age, but this in turn fails to explain the occurrence of Miocene tholeiites on the Ethiopian and Somalian plateaus. It therefore seems that an association of plateau tholeiites and alkali basalts is intimate and complex and that 'oceanic' and 'continental' tholeiites are distinct entities [Schilling, 1969].

Several earlier workers [e. g. , Hieke-Merlin, 1950, 1953; Comucci, 1950] have used Niggli values to investigate the chemistry of the Ethiopian volcanics. Niggli values are currently finding favor as a means of determining inter-oxide relationships independently of variations in silica content [Leake, 1970]. McBirney and Gass [1967] found QZ values to be the most sensitive single parameter in the pattern of volcanic variations across midoceanic ridges.

The Ethio-Yemen basalts have been plotted on various Niggli diagrams, but no new distinctions between rift and plateau emerge that are not evident from oxide percentages. The lowest $Q Z$ values are restricted to plateau basalts, and the Quaternary basalts of the Yemen highlands and the Tana rift plot among these lowest $Q Z$ values (they also have higher $\mathrm{Mg} / \mathrm{Fe}$ than the older plateau basalts). Figure 4 shows a plot of K/SI that tends to separate the potash-rich plateau basalts from the rift basalts. There appears to be a degree of inverse K/SI behavior among the plateau basalts, with the most undersaturated basalts having the highest $K$ values. A plot of ALK/C fails to distinguish separate fields for $r$ ift and plateau basalts (Figure 4), but there are some notable high $\mathrm{C}-$ low ALK basalts from the Yemen and the Danakil horst [Comucci, 1928 ].

Intermediate volcanics. The intermediate volcanics show greater distinction between rift and plateau than do either basalts or silicics. For the Ethiopian region (excluding $\mathrm{Y}$ emen), $\mathrm{K}_{2} \mathrm{O}, \mathrm{TiO}_{2}, \mathrm{MgO}$, and especially $\mathrm{CaO}$ provide possible single discriminants, and associations of the se oxides and also of volatiles would undoubtedly improve discrimination. The Yemen intermediates have lower $\mathrm{Mg} / \mathrm{Fe}$ than do the Ethiopian intermediates, and like the Yemen basalts, include members with very high Niggli $\mathrm{C}$ and low ALK values. 
The rift intermediates have a calc-alkaline tendency that is quite distinct from the peralkaline nature of the plateau intermediates. The plateau intermediates magnify a feature of the plateau basalts in showing strong potash enrichment relative to soda. In this regard, some field relationships are noteworthy. Whereas the rift intermediates are usually intimately associated with more voluminous units of alkaline rhyolite, the plateau intermediates form plugs, stocks, and thick flows that often lack associated silicics or basalts. The rift intermediates can therefore be considered to lie on a general line of crystal fractionation (or extensive partial melting at depth), whereas the plateau intermediates are considered to be derived from an independent magmatic source [see also Williams, 1970].

Like the basalts, the intermediate volcanics of the plateau are less saturated in terms of normative quartz and Niggli QZ values, are more oxidized, and are much more salic compared with the $r$ ift volcanics. The excessively salic and alkaline (especially potasic) character of the plateau intermediates makes it difficult to explain their origin in terms of normal fractionation from or partial melting of alkali olivine basalt such as forms the bulk of the Trap Series and Shield Group. The ALK - C diagrams in Figure 4 suggest a discontinuity between plateau basalts and intermediates (such as is not found for the rift volcanics), with the latter affected by alkali enrichment. The same problem arises in exacerbated form for the ultra-potassic trachytes and phonolites of the East African plateau; both Sutherland [1 965 ] and Nixon and Clark [1967] note the inadequacy of normal fractionation processes to generate these rocks; they propose a crustal origin involving fenitisation and mobilization.

The question occurs as to whether the magmas supplying the alkali olivine basalts of the plateau ever gave rise to fractionated intermediate derivatives. On the basis of known field evidence, such possible derivatives appear peculiarly rare in Ethiopia and Yemen. Molly [1934] considers that the Ethiopian phonolites are intimately related to contemporaneous basalts (basanites?), whereas the trachytes are associated with andesites. Even if Molly's conclusions are accepted, however, the overwhelming proportion of Ethiopian basalts show no associated phonolites. Similar objections to a 
partial fusion origin for the plateau intermediates derive from the infrequency of associated silicic lavas, unless the degree of basaltic fusion was peculiarly consistent.

Silicic volcanics. Tables 2 and 3 reveal less distinction between plateau and rift silicics than for the intermediates and basalts. Possible distinctions have been tentatively suggested by Mohr [1970b], who has emphasized the influence of local anomalies on any general interpretation. Thus, although the rift tends to be characterized by pantelleritic and the plateau by comenditic rhyolites, occurrences of pantellerite are known from the southern Ethiopian plateau and of comendite from central Afar. All that can be stated on the basis of Tables 2 and 3 is that the rift silicics have higher $\mathrm{Na} / \mathrm{K}$ than do the plateau silicics and, like the intermediates, may be less oxidized. Degrees of oversaturation and femicity are almost identical.

Nevertheless, Figure 4 shows that Niggli plots reveal separate tendencies between plateau and rift volcanics. The rift silicics fall into the lowvalue corner of the $M G-Q Z$ diagram, with the Chabbi obsidians [Macdonald and Gibson, 1969] having higher QZ values than do the Afar silicics, perhaps owing to their situation well inside the continental African shield. The rift silicics also fall into the low-value corner of the K/SI plot, excepting those of the Gulf of Tajura region. A possible direct K/SI relationship exists, except when the SI values reach above 500. The AL-ALK/FM plot again places the rift silicics in a lower-value field, with a clear inverse relationship between these two parameters. The Jimma pantellerites of the southern Ethiopian plateau fall well inside the rift field [Mohr, $1970 \mathrm{~b}$.

McBirney [1969] states that extensive rhyolitic ignimbrites are characteristic of continental epeirogenic tectonism, whereas in oceanic regions only small quantities of pantellerite-comendite occur. If, on the basis of its sialic crust, the Ethiopian swell is considered to be a continental tectonic phenomenon rather than one analogous to a mid-oceanic ridge, then the enormous extent of silicic ignimbrites confirms McBirney's observation, though the Ethiopian ignimbrites are pantelleritic [Mohr, 1968]. McBirney 
further notes that "the extreme composition and great volume of rhyolitic ignimbrites places a severe constraint [on their possible genesis] "and concludes that large-scale crustal fusion is a more plausible explanation than is crystal fractionation. Barberi et al. [1970] postulate as similation of sialic crust to explain the large quantities of 'variegated' silicic volcanics in northern and central Afar, excluding the Erta-ali and Ala-ita silicics, whose low $\mathrm{Sr}^{87} / \mathrm{Sr}^{86}$ values suggest an uncontaminated mantle origin. This presumption of sialic crust under Afar, supported by geological and other evidence [ Jones, 1968; Mohr, 1962, 1967], introduces well-known problems for the original geometric fit of Arabia against Africa.

Sigurdsson [1967] has discussed the origin of the silicic lavas of Iceland in view of the absence of a pre-volcanic sialic crust there and is forced to conclude that differentiation from basaltic magma is the only obvious source. Gibson [1969] has suggested the possibility that partial fusion of solid basalt, rather than differentiation from basaltic magma, has been the source for the Icelandic silicic lavas. Both mechanisms are feasible, but both seem equally inadequate to provide the voluminous quantities of silicic magma erupted in Ethiopia during the Neogene (see also Sigurdsson [1967], p. 39). Taking the case of partial fusion, the required thermal conditions at the base of the crust are too discrete to be at all probable. Assuming favorable conditions such that $5 \%$ of basalt is partially fused to yield silicic magma, 1 million $\mathrm{km}^{3}$ of basalt are required to provide the $50,000 \mathrm{~km}^{3}$ of Ethiopian Neogene silicics. The Upper Pliocene ignimbrites make up the bulk of this volume, and as their occurrence in south-central Ethiopia covers a maximum of $150,000 \mathrm{~km}^{2}$, there is a required partial fusion of a $6-\mathrm{km}$-thick plate of underlying basalt. In view of the temperature gradient that would exist through a plate of this thickness, such a model is implausible.

The question therefore turns on whether sialic crust is indeed present under Afar and the main Ethiopian rift. If such crust is absent, then the relatively few strong differences in rift and plateau silicic chemistry are puzzling, accepting the respective conclusions of Sigurdsson and McBirney that the former rocks likely result from fractionation and the latter from 
crustal fusion. Either the rift in Ethiopia is underlain by sialic crust or else the plateau ignimbrites have a subcrustal origin unrelated to the upper sialic crust. Or possibly the upper mantle is heterogeneous in a manner related to the lower crustal compositions of $r$ ift and plateau.

One possible escape from the silicic dilemma follows from the suggestion of Sigurdsson ([1967] p. 42) that silicic magma, generated from the upper mantle, accretes and solidifies at the base of the crust, thereby producing a thin sialic layer with mantle isotope-ratio characteristics. This is in line with several theories of continental evolution during Earth history (see Hurley [1968]). Increased heat-flow during rifting could melt large portions of this sialic material (whose presence may contribute to the Bouguer anomaly pattern over the Ethiopian swell - Gouin [1970]), and thus generate voluminous silicic magma. This hypothesis would help explain the presence of alkali syenite and granite xenoliths in many Ethiopian silicic volcanic rocks [Mohr, $1963]$.

\section{CONCLUSIONS}

The strong suggestion of distinctive chemistry between rift and plateau volcanics in Ethiopia and Yemen is shown: for the basalts in a more undersaturated and alkali-rich character on the plateau; for the interrnediates in a less saturated, less calcic, less femic, and more peralkaline character on the plateau; and for the silicics in a more oversaturated, less sodic character on the plateau. In all three classes, $\mathrm{Na} / \mathrm{K}$ is higher in the $\mathrm{r}$ ift volcanics: in the basalts and intermediates, this is largely due to potash enrichment for the plateau (more probable than a potash depletion in a rift environment), but in the silicics it is due to soda enrichment [Mohr, 1970b].

On the basis of crystal fractionation processes, it is conceivable that the plateau intermediates could be linked with the rare melanephelinites of the plateau, though field associations are even rarer. But if the plateau silicics are products of strong fractionation of plateau basaltic magma, then they have not passed through a preserved intermediate stage; plateau intermediates are too peralkaline and salic to provide such a link. 
It is easier to conceive a continuous line of descent for the $r$ ift volcanics. Rift basalts, trachybasalts, and mugearites are found in intimate field assocciations, as are trachyrhyolites and rhyolites, but there is still strong evidence for a hiatus in the intermediate range [Tazieff et al., 1970; Barberi et al. , 1970].

The scheme of Harris [1967] applies well to explaining the chemistry of the Ethio-Yemen basalts: a steeper thermal gradient under the rift can allow extensive shallow-depth melting, resulting in generation of basalt magma with tholeitic tendencies. A shallow thermal gradient through the thick sialic crust of the plateau enforces deep melting, with the generation of alkali basalt that may not always reach the surface immediately, resulting in formation of accumulates.

Barberiet al. [1970] distinguish two types of silicic volcanics in Afar according to the presumed presence or absence of sialic crust affecting processes of assimilation. However, the enormous volumes of rhyolitic ignimbrites in Ethiopia, dissociated from any basaltic activity, lead the author to support McBirney's [1969] hypothesis of a melted crustal source, though Mohr [1970b] has indicated that granitic crust could not alone account for the chemistry of these peralkaline ignimbrites. Large-scale assimilation as a source for the silicic magmas is unlikely on the evidence of Dickinson and Hatherton [1967] for andesites. The author therefore supports Sigurdsson's [1967] suggestion that silicic volcanics in a rift environment are derived from remelting of a lower crustal sialic layer derived from accretion from upper mantle processes.

Schilling [1970] emphasizes the distinctions that must be expected between continental and oceanic-rift volcanism. Whereas mass transport is more important than conduction in effecting heat los from the mantle under the oceanic ridges, where the low-velocity layer lies relatively close to the surface, conduction is the only significant heat-loss mechanism through continental crust. Furthermore, the generation of radiogenic heat within thick sialic crust further reduces the heat flow from the underlying mantle. 
Thus magmatic processes can evolve further under continental compared with oceanic rifts, with resulting fractionation, assimilation, and crustal-fusion processes showing in the chemistry of the continental volcanics [Schilling, 1970].

The question of whether the Ethio-Yemen volcanics have undergone a temporal chemical evolution can be reexamined. Because the rift volcanics are largely younger than the plateau volcanics, it is now seen that the temporal trends identified by Mohr [1963] are affected by those of provenance as discussed in this paper. For example, the higher femicity and Fe/Mg of rift basalts, intermediates, and silicics noted here confirm what was previously interpreted as a regional temporal evolution. And the Quaternary basalts of the Lake Tana and Yemen highlands regions resemble the early Tertiary plateau basalts rather than the Quaternary $r$ ift basalts in composition. Nevertheless, Sigvaldason [1969] presents some evidence for long-term chemical evolution in magma-basalt generation in the Icelandic $r$ ift zone, so the problem remains open until more data are available.

Acknowledgment. The author is grateful to Dr. I. L. Gibson who originally pointed out the value of making a comparative study of plateau and rift volcanism in Ethiopia. This work was supported in part by grant NGR 09-015-002 from the National Aeronautics and Space Administration. 


\section{REFERENCES}

Aumento, F., Magmatic evolution on the mid-Atlantic ridge, Earth Planetary Sci. Letters, 2, 225-230, 1967.

Aumento, F., The mid-Atlantic ridge near $45^{\circ} \mathrm{N}$. II. Basalts from the area of Confederation Peak, Can. J. Earth Sci., 5, 1-21, 1968.

Baker, B. H., and P. A. Mohr, Geology of the eastern rift system of Africa, submitted to Bull. Geol. Soc. Am., 1970.

Barberi, F., S. Borsi, G. Ferrara, G. Marinelli, and J. Varet, Relationships between tectonics and magmatology of the northern Afar (or Danakil) Depression, Phil. Trans. Roy. Soc. (London), in press, 1970.

Bullard, E. C., The origin of the oceans, Scientific Am. , 221, no. 3, pp. $66-75,1969$.

Comucci, P., Contributo allo studio delle rocce effusive della Dancalia, Mem. Soc. Toscana Sci. Nat. , 39, 93-113, 1928.

Comucci, P., Le vulcaniti del lago Tana (Africa Orientale), Atti. Accademia Nazionale Lincei (Roma), 209 pp. , 1950.

Dickinson, W. R., and T. Hatherton, Andesitic volcanism and seismicity around the Pacific, Science, 157, 801-803, 1967.

Gass, I. G., Evolution of volcanism in the junction area (of the Red Sea, Gulf of Aden and Ethiopian rifts), Phil. Trans. Roy. Soc. (London), in press, 1970.

Gass, I. G., and I. I. Gibson, Structural evolution of the rift zones in the Middle East, Nature, 221, 926-930, 1969.

Gass, I. G., and D. I. J. Mallick, Jebel Khariz: an Upper Miocene stratovolcano of comenditic affinity on the South Arabian coast, Bull. Volcan., 32, $33-88,1968$.

Gibson, I. L., Origin of some Icelandic pitchstones, Lithos, 2, 343-349, 1969. 
Gortani, M., Il problema delle fosse tettoniche africane e le ricerche italiane in Dancalia, Mem. Roy. Acad. Sci. Inst. Bologna, 6, 1-18, 1950.

Gouin, P., Seismic and gravity data from Afar, Phil. Trans. Roy. Soc. (London), in press, 1970.

Harkin, D. A. The Rungwe volcanics at the northern end of Lake Nyasa, Mem. Geol. Surv. Tanganyika, II, 172 pp., 1960.

Harris, P. G., Basalt type and rift valley tectonism, Presented at the International Union of Geodesy and Geophysics, Zurich, 1967.

Hieke-Merlin, O. , I basalti dell'Africa Orientale, Mem. Inst. Geol. Mineral. Univ. Padova, 17, 42 pp., 1950.

Hieke-Merlin, $\mathrm{O}$, Le vulcaniti acide dell'Africa Orientale, Mem. Inst.

Geol. Mineral. Univ. Padova, 18, 45 pp. , 1953.

Hurley, P. M., Absolute abundance and distribution of $\mathrm{Rb}, \mathrm{K}$ and $\mathrm{Sr}$ in the Earth, Geochim. Cosmochim. Acta, 32, 273-283, 1968.

Jones, P. B., Surface seismic wave dispersion and crustal structure between Gulf of Aden and Addis Ababa, Bull. Geophys. Obs. Addis Ababa, 12, 19-26, 1968.

Laughton, A. S., The Gulf of Aden, Phil. Trans. Roy. Soc. (London), 259A, $150-171,1966$.

Leake, B. E., Some paradoxes in Australasian microtektite compositional trends, J. Geophys. Res., 75, 349-356, 1970.

Le Bas, M. J., and P. A. Mohr, Feldspathoidal rocks from the Cainozoic volcanic province of Ethiopia, Geol. Rundsch., 58, 273-280, 1968.

Le Bas, M. J., and P. A. Mohr, Tholeiite from the Simien alkali basalt centre, Ethiopia, Geol. Mag. , Contrib. Miner. Pet. , 24, 239-244, 1969.

Macdonald, R., and I. L. Gibson, Pantelleritic obsidians from the volcano Chabbi (Ethiopia), Contrib. Miner. Pet., 24, 239-244, 1969.

Manasse, E. , Contribuzioni allo Studio Petrografico della Colonia Eritrea, Siena, 169 pp. , 1909.

McBirney, A. R., Andesitic and rhyolitic volcanism of orogenic belts, in: The Earth's Crust and Upper Mantle, edited by P. J. Hart, Amer. Geophys. Union, Geophys. Mono. 13, pp. 501-507, 1969. 
McBirney, A. R., and I. G. Gass, Relations of oceanic volcanic rocks to mid-oceanic rises and heat flow, Earth Planetary Sci. Letters, $\underline{2}$, 265-276, 1967.

Mohr, P. A., The Ethiopian rift system, Bull. Geophys. Obs. Addis Ababa, 3 (serial no. 5), 33-62, 1962.

Mohr, P. A., The Ethiopian Cainozoic lavas - a preliminary study of some trends: spatial, temporal, and chemical, Bull. Geophys. Obs. Addis Ababa, $\underline{3}$ (serial no. 6), 103-144, 1963.

Mohr, P. A., The Ethiopian rift system, Bull. Geophys. Obs. Addis Ababa, $11,1-65,1967$.

Mohr, P. A., The Cainozoic volcanic succession in Ethiopia, Bull. Volcan., 32, $5-14,1968$.

Mohr, P. A., Catalogue of chemical analyses of rocks from the intersection of the African, Gulf of Aden, and Red Sea rift systems, Smithsonian Contrib. Earth Sci., in press, 1970a.

Mohr, P. A., Volcanic composition in relation to tectonics in the Ethiopian rift system: a preliminary investigation, Bull. Volcan., 34 , in press, $1970 \mathrm{~b}$.

Mohr, P. A., and A. S. Rogers, Gravity traverses in Ethiopia (second interim report), Bull. Geophys. Obs. Addis Ababa, 9, 7-58, 1966.

Molly, E., Etudes pétrographiques en Ethiopie: 3, observations sur les roches alkalines d'Abyssine, C.R. Soc. Phys. Hist. Nat. Genève, 51 , $76-79,1934$.

Niazi, M., Crustal thickness in the central Saudi Arabian Peninsula, Geophys. J. , 15, 545-547, 1968.

Nixon, P. H., and L. Clark, The alkaline centre of Yelele and its bearing on the petrogenesis of other eastern Uganda volcanoes, Geol. Mag., $104,455-472,1967$.

Prior, G. T., Contribution to the petrology of British East Africa, Mineral. Mag., 13, 228-263, 1903.

Raisin, C. A., Petrological notes on rocks from southern Abyssinia, Quart. J. Geol. Soc. London, 59, 292-306, 1903.

Roman, D , Studii petrografice in Yemen (Regiunea Hodeida - Saana), Ann. Inst. Geol. Romania, 11, 207-299, 1926. 
Saggerson, E. P., and L. A. J. Williams, Ngurumanite from southern Kenya and its bearing on the origin of rocks in the northern Tanganyika alkaline district, J. Petrol. , 5, 40-81, 1964 .

Schilling, J. -G. , Red Sea floor origin: rare-earth evidence, Science, 165, $1357-1359,1969$.

Schilling, J.-G, Sea-floor evolution: rare-earth evidence, in Proc. Symp. The Petrology of Igneous and Metamorphic Rocks from the Ocean Floor, London (circulated preprint), 1970.

Shukri, N. M., and E. Z. Basta, Petrography of the alkaline volcanic rocks of Yaman, Bull. Inst. d'Egypte, 36, 129-164, 1955.

Sigurdsson, H., The Icelandic basalt plateau and the question of sial, in: Iceland and Mid-Ocean Ridges, edited by S. Björnsson, Soc. Sci. Islandica, 38, pp. 32-49, 1967.

Sigvaldason, G. E., Chemistry of basalts from the Icelandic rift zone, Contrib. Mineral. Petrol., 20, 357-370, 1969.

Sutherland, D. S, Potash-trachytes and ultra-potassic rocks associated with the carbonatite complex of the Toror Hills, Uganda, Mineral. Mag. , 35, 363-378, 1965 .

Tazieff, H., G. Marinelli, F. Barberi, and J. Varet, Geologie de 1'Afar septentrional, Bull. Volcan., in press, 1970.

Tazieff, H. , and J. Varet, Signification tectonique et magmatique de 1'Afar septentrional (Ethiopie), Rev. Geog. Phys. Geol. Dynam., 11, 429-450, 1969.

Tramontini, C., and D. Davies, A seismic refraction survey in the Red Sea, Geophys. J., 17, 225-241, 1969.

Weber, M., Die petrographische Ausbeute der expeditionen $O$. Neumann v. Erlanger nach Ostafrika und Abessynien 1900-1901, Mitt. Munchen Geog. Gesellsch. , 1, 637-660, 1906.

Williams, L.A. J., Volcanic as sociations in the Gregory Rift Valley, East Africa, Nature, 224, 61-64, 1969.

Williams, L.A.J., Geochemistry and petrogenesis of the Kilimanjaro volcanic rocks of the Amboselli area, Kenya, Bull. Volcan., 33, in press, 1970.

Wright, J. B., Petrographic sub-provinces in the Tertiary to Recent volcanics of Kenya, Geol. Mag., 102, 541-557, 1965. 
Yoder, H. S., Jr., and C. E. Tilley, Origin of basalt magmas: an experimental study of natural and synthetic rock systems, J. Petrol., 3, $342-532,1962$. 


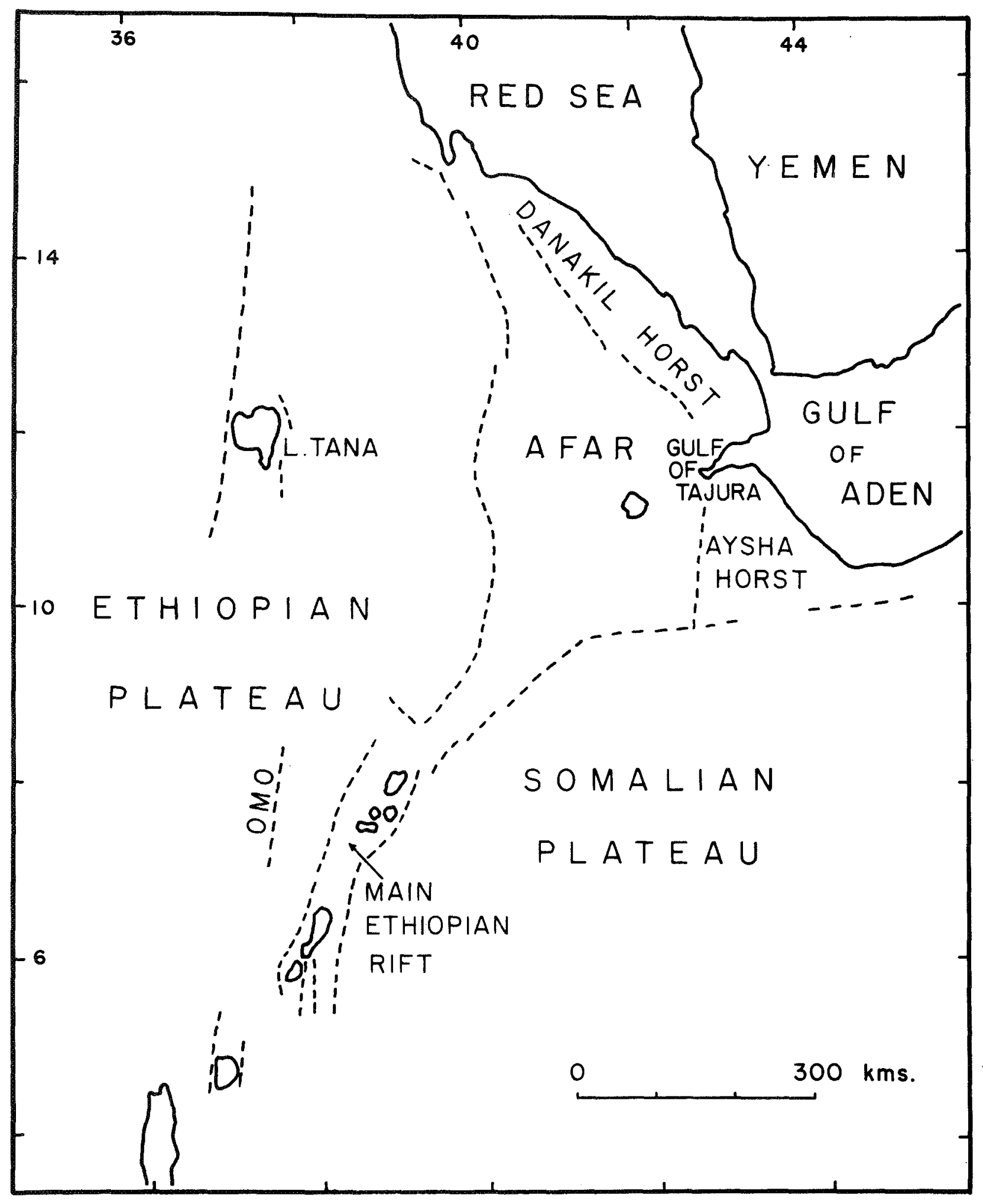

Fig. 1. Location map of Horn of Africa. 


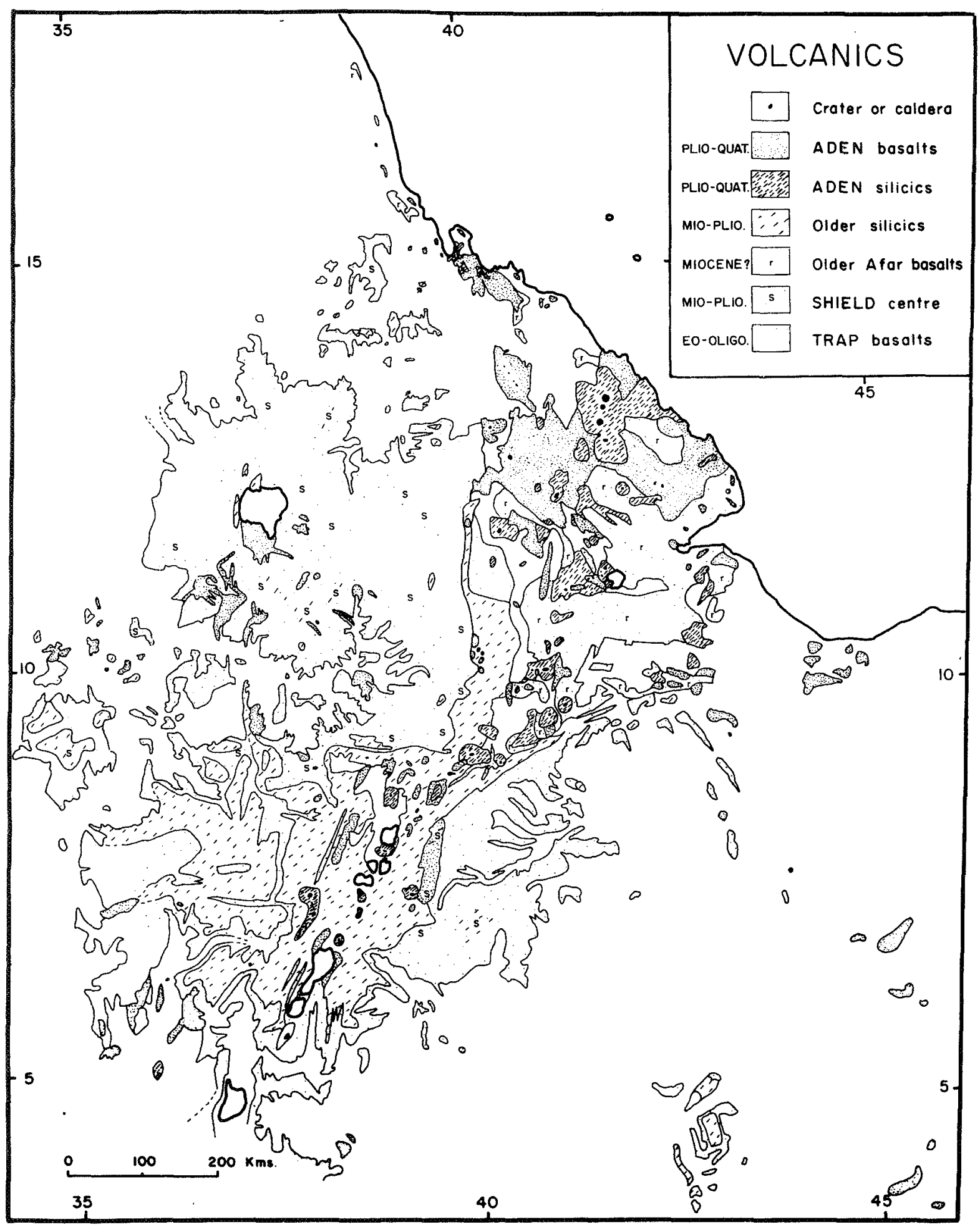

Fig. 2. Volcanological sketch map of Ethiopia (reproduced from Mohr, 1967). 


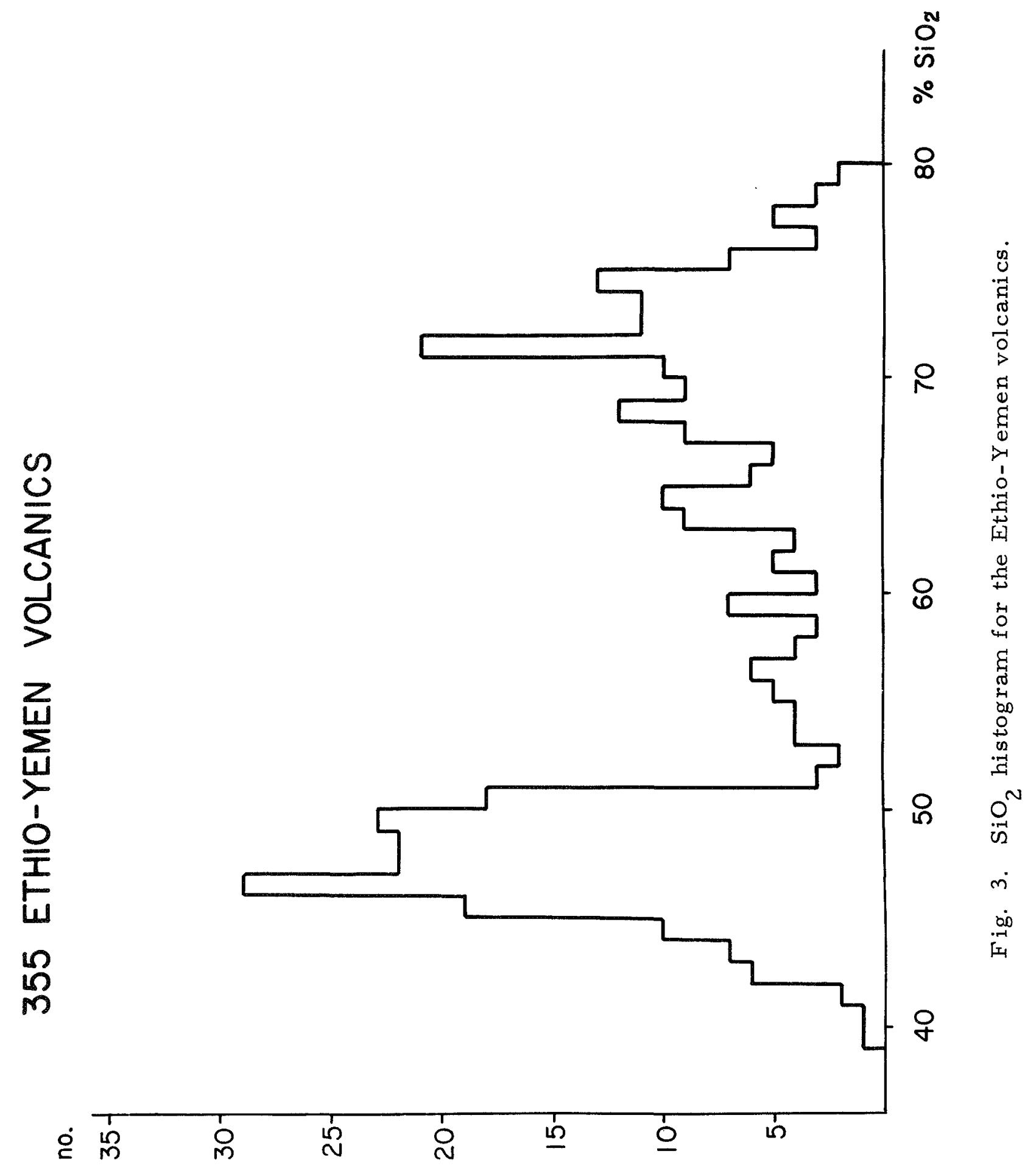




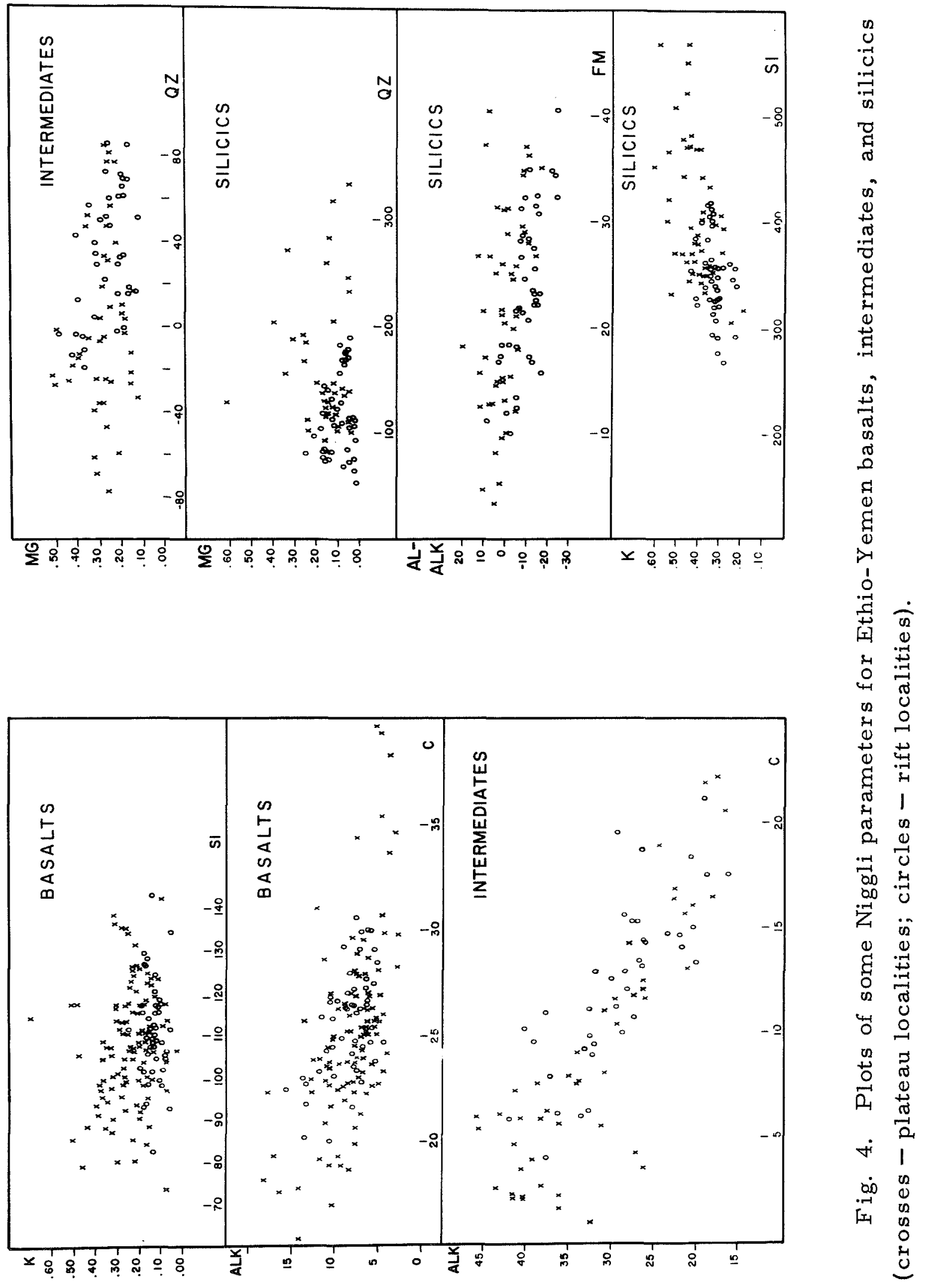


TABLE 1. Average Compositions of Volcanic Rocks from the Horn of Africa and Yemen

\begin{tabular}{|c|c|c|c|c|c|}
\hline & 1 & 2 & 3 & 4 & 5 \\
\hline $\mathrm{SiO}_{2}$ & $47.1 \pm 1.7$ & $49.1 \pm 1.2$ & $62.0 \pm 3.5$ & $71.6 \pm 2.5$ & $73.5 \pm 3.4$ \\
\hline $\mathrm{TiO}_{2}$ & $2.3 \pm 1.1$ & $1.7 \pm 0.6$ & $0.6 \pm 0.5$ & $0.3 \pm 0.2$ & $0.2 \pm 0.2$ \\
\hline $\mathrm{Al}_{2} \mathrm{O}_{3}$ & $15.2 \pm 2.6$ & $13.9 \pm 1.5$ & $15.1 \pm 2.5$ & $11.1 \pm 2.3$ & $11.5 \pm 1.7$ \\
\hline $\mathrm{Fe}_{2} \mathrm{O}_{3}$ & $5.7 \pm 3.1$ & $4.9 \pm 2.0$ & $4.3 \pm 2.3$ & $3.1 \pm 2.0$ & $3.0 \pm 1.7$ \\
\hline $\mathrm{FeO}$ & $7.5 \pm 2.8$ & $7.9 \pm 1.6$ & $2.7 \pm 2.3$ & $2.2 \pm 1.7$ & $1.0 \pm 0.9$ \\
\hline $\mathrm{MnO}$ & $0.2 \pm 0.3$ & $0.3 \pm 0.4$ & $0.3 \pm 0.3$ & $0.2 \pm 0.2$ & $0.1 \pm 0.2$ \\
\hline $\mathrm{MgO}$ & $5.9 \pm 1.7$ & $7.2 \pm 3.0$ & $0.8 \pm 0.7$ & $0.2 \pm 0.2$ & $0.4 \pm 0.4$ \\
\hline $\mathrm{CaO}$ & $10.0 \pm 1.6$ & $11.1 \pm 1.4$ & $2.6 \pm 1.6$ & $0.9 \pm 0.7$ & $0.8 \pm 0.7$ \\
\hline $\mathrm{Na}_{2} \mathrm{O}$ & $3.1 \pm 0.9$ & $2.0 \pm 0.5$ & $5.7 \pm 1.6$ & $5.5 \pm 0.9$ & $3.5 \pm 1.0$ \\
\hline $\mathrm{K}_{2} \mathrm{O}$ & $1.3 \pm 0.9$ & $0.6 \pm 0.3$ & $4.3 \pm 1.4$ & $4.0 \pm 0.7$ & $4.7 \pm 0.8$ \\
\hline $\mathrm{P}_{2} \mathrm{O}_{5}$ & $0.3 \pm 0.3$ & $0.3 \pm 0.3$ & $0.2 \pm 0.2$ & $0.1 \pm 0.1$ & $0.1 \pm 0.2$ \\
\hline $\mathrm{H}_{2} \mathrm{O}(+)$ & $1.4 \pm 1.1$ & $1.0 \pm 0.7$ & $1.4 \pm 1.4$ & $0.8 \pm 0.8$ & $1.2 \pm 1.1$ \\
\hline$\cdot$ & 100.0 & 100.0 & 100.0 & 100.0 & 100.0 \\
\hline$Q$ & - & 3.2 & 7.5 & 24.7 & 33.7 \\
\hline OR & 7.8 & 3.6 & 25.9 & 23.9 & 28.2 \\
\hline$A B$ & 26.7 & 17.1 & 49.0 & 35.0 & 30.0 \\
\hline$A N$ & 24.0 & 27.4 & 2.9 & - & 1.8 \\
\hline $\mathrm{AC}$ & - & - & - & 9.1 & - \\
\hline NS & - & - & - & 0.4 & - \\
\hline DI & 19.8 & 21.4 & 6.2 & 3.4 & 1.3 \\
\hline wo & - & - & 0.6 & - & - \\
\hline HY & 0.7 & 16.1 & - & 2.7 & 0.4 \\
\hline OL & 7.5 & - & - & - & - \\
\hline $\mathrm{MT}$ & 8.4 & 7.2 & 6.3 & - & 3.0 \\
\hline $\mathrm{HM}$ & - & - & - & - & 1. 0 \\
\hline IL & 4.4 & 3.3 & 1.2 & 2.6 & 0.4 \\
\hline AP & 0.7 & 0.7 & 0.4 & 0.2 & 0.2 \\
\hline $\mathrm{QZ}$ & -27 & -9 & +7 & +119 & +168 \\
\hline
\end{tabular}

. Average of 98 alkaline basalts.

2. Average of 9 calc-alkaline basalts

3. Average of 68 intermediates.

4. Average of 75 sodic rhyolites.

5. Average of 37 potassic rhyolites. 
TABLE 2. Compositional Comparisons between Plateau and Rift Volcanics in Ethiopia and Yemen

\begin{tabular}{|c|c|c|c|c|c|c|}
\hline & $1 \mathrm{P}$ & $1 \mathrm{R}$ & $2 \mathrm{P}$ & $2 \mathrm{R}$ & $3 P$ & $3 R$ \\
\hline $\mathrm{SiO}_{2}$ & $46.7 \pm 2.4$ & $48.1 \pm 1.7$ & $60.6 \pm 3.6$ & $59.9 \pm 3.3$ & $72.4 \pm 3.1$ & $72.7 \pm 2.3$ \\
\hline $\mathrm{TiO}_{2}$ & $2.2 \pm 1.1$ & $2.2 \pm 1.0$ & $0.4 \pm 0.4$ & $1.2 \pm 0.5$ & $0.2 \pm 0.2$ & $0.3 \pm 0.2$ \\
\hline $\mathrm{Al}_{2} \mathrm{O}_{3}$ & $14.8 \pm 2.8$ & $14.0 \pm 2.8$ & $16.6 \pm 2.4$ & $14.3 \pm 2.5$ & $11.1 \pm 2.2$ & $10.9 \pm 2.0$ \\
\hline $\mathrm{Fe}_{2} \mathrm{O}_{3}$ & $5.4 \pm 3.0$ & $5.6 \pm 2.7$ & $4.3 \pm 2.3$ & $4.5 \pm 2.1$ & $3.2 \pm 1.9$ & $2.8 \pm 2.0$ \\
\hline $\mathrm{FeO}$ & $7.5 \pm 2.5$ & $7.9 \pm 2.7$ & $2.1 \pm 2.1$ & $4.5 \pm 2.6$ & $1.8 \pm 1.8$ & 2. $0 \pm 1.2$ \\
\hline $\mathrm{MnO}$ & $0.2 \pm 0.2$ & $0.2 \pm 0.1$ & $0.3 \pm 0.3$ & $0.3 \pm 0.2$ & $0.2 \pm 0.3$ & $0.1 \pm 0.1$ \\
\hline $\mathrm{MgO}$ & $6.8 \pm 2.8$ & $6.2 \pm 1.8$ & $0.6 \pm 0.7$ & $1.5 \pm 0.8$ & $0.3 \pm 0.3$ & $0.3 \pm 0.2$ \\
\hline $\mathrm{CaO}$ & $10.1 \pm 2.5$ & $10.7 \pm 1.9$ & $2.2 \pm 1.5$ & $4.1 \pm 1.2$ & $0.9 \pm 0.6$ & $0.8 \pm 0.7$ \\
\hline $\mathrm{Na}_{2} \mathrm{O}$ & $2.8 \pm 1.3$ & $2.8 \pm 0.7$ & $6.2 \pm 1.8$ & $5.4 \pm 1.3$ & $4.6 \pm 1.4$ & $5.2 \pm 1.0$ \\
\hline $\mathrm{K}_{2} \mathrm{O}$ & $1.5 \pm 1.1$ & $0.9 \pm 0.5$ & $4.9 \pm 1.4$ & $2.9 \pm 1.0$ & $4.3 \pm 0.8$ & $4.2 \pm 0.7$ \\
\hline $\mathrm{P}_{2} \mathrm{O}_{5}$ & $0.3 \pm 0.3$ & $0.3 \pm 0.2$ & $0.2 \pm 0.2$ & $0.4 \pm 0.3$ & $0.1 \pm 0.2$ & $0.0 \pm 0.1$ \\
\hline \multirow[t]{2}{*}{$\mathrm{H}_{2} \mathrm{O}(+)$} & $1.7 \pm 1.2$ & $1.1 \pm 1.0$ & $1.6 \pm 1.7$ & $1.0 \pm 0.6$ & $0.9 \pm 0.7$ & $0.7 \pm 0.8$ \\
\hline & 100.0 & 100.0 & 100.0 & 100.0 & 100.0 & 100.0 \\
\hline$Q$ & - & - & 1.9 & 8.4 & 28.3 & 26.9 \\
\hline OR & 9.0 & 5.4 & 29.5 & 17.3 & 25.7 & 25.0 \\
\hline$A B$ & 23.9 & 24.0 & 53.4 & 46.3 & 33.4 & 32.9 \\
\hline AN & 23.8 & 23.2 & 3.0 & 6.2 & - & - \\
\hline $\mathrm{NE}$ & 0.1 & - & - & - & - & - \\
\hline $\mathrm{AC}$ & - & - & - & - & 5.3 & 8.2 \\
\hline NS & - & - & - & - & - & 0.5 \\
\hline DI & 20.5 & 23.2 & 3.7 & 9.9 & 3.4 & 3.5 \\
\hline wo & - & - & 1.0 & - & - & - \\
\hline HY & - & 10.9 & - & 2.1 & 1.2 & 2.4 \\
\hline OL & 9.8 & 0.2 & - & - & - & - \\
\hline $\mathrm{MT}$ & 8.0 & 8.2 & 6.3 & 6.6 & 2.1 & - \\
\hline IL & 4.2 & 4.2 & 0.8 & 2.3 & 0.4 & 0.6 \\
\hline AP & 0.7 & 0.7 & 0.4 & 0.9 & 0.2 & 0.0 \\
\hline $\mathrm{QZ}$ & -27 & -20 & -10 & +6 & +136 & +136 \\
\hline Femics (\%) & 42 & 47 & 11 & 21 & 12 & 15 \\
\hline
\end{tabular}

1P. Average of 80 plateau basalts.

$1 R$. Average of 52 rift basalts.

2P. Average of 35 plateau intermediates.

2R. Average of 15 rift intermediates.

3P. Average of 52 plateau silicics.

$3 R$. Average of 42 rift silicics. 
TABLE 3. Compositional Comparisons between Plateau and Rift Volcanics in Ethiopia

\begin{tabular}{|c|c|c|c|c|c|c|}
\hline . & $l P$ & $1 R$ & $2 P$ & $2 \mathrm{R}$ & $3 P$ & $3 R$ \\
\hline $\mathrm{SiO}_{2}$ & 47. $0 \pm 2.1$ & $48.1 \pm 1.7$ & $61.1 \pm 3.6$ & $59.2 \pm 2.8$ & $72.4 \pm 2.8$ & $72.7 \pm 2.3$ \\
\hline $\mathrm{TiO}_{2}$ & $2.1 \pm 0.9$ & $2.2 \pm 1.0$ & $0.5 \pm 0.4$ & $1.2 \pm 0.5$ & $0.3 \pm 0.2$ & $0.2 \pm 0.2$ \\
\hline $\mathrm{Al}_{2} \mathrm{O}_{3}$ & $15.2 \pm 2.6$ & $13.6 \pm 2.9$ & $16.9 \pm 2.5$ & $14.4 \pm 2.9$ & $10.9 \pm 2.2$ & $11.0 \pm 2.0$ \\
\hline $\mathrm{Fe}_{2} \mathrm{O}_{3}$ & $4.6 \pm 2.3$ & $5.7 \pm 2.9$ & $3.6 \pm 1.5$ & 4. $3 \pm 2.0$ & $3.0 \pm 1.7$ & $2.5 \pm 1.8$ \\
\hline $\mathrm{FeO}$ & $7.9 \pm 2.3$ & $8.1 \pm 2.9$ & $2.2 \pm 2.1$ & $5.0 \pm 2.9$ & $2.2 \pm 1.9$ & $2.0 \pm 1.2$ \\
\hline $\mathrm{MnO}$ & $0.2 \pm 0.1$ & $0.2 \pm 0.1$ & $0.2 \pm 0.3$ & $0.3 \pm 0.2$ & $0.1 \pm 0.1$ & $0.1 \pm 0.1$ \\
\hline $\mathrm{MgO}$ & $6.9 \pm 2.7$ & $6.2 \pm 1.7$. & $0.5 \pm 0.4$ & $1.6 \pm 0.8$ & $0.2 \pm 0.2$ & $0.3 \pm 0.2$ \\
\hline $\mathrm{CaO}$ & $9.7 \pm 2.2$ & $10.7 \pm 2.0$ & $1.9 \pm 1.1$ & $4.5 \pm 1.0$ & $0.7 \pm 0.5$ & $0.8 \pm 0.7$ \\
\hline $\mathrm{Na}_{2} \mathrm{O}$ & $3.0 \pm 1.3$ & $2.7 \pm 0.6$ & $6.3 \pm 1.8$ & $5.3 \pm 1.5$ & $5.0 \pm 1.2$ & $5.4 \pm 1.0$ \\
\hline $\mathrm{K}_{2} \mathrm{O}$ & $1.6 \pm 1.2$ & $1.0 \pm 0.6$ & $5.1 \pm 1.3$ & $2.8 \pm 1.2$ & $4.4 \pm 0.6$ & $4.3 \pm 0.7$ \\
\hline $\mathrm{P}_{2} \mathrm{O}_{5}$ & $0.3 \pm 0.2$ & $0.3 \pm 0.2$ & $0.1 \pm 0.1$ & $0.4 \pm 0.3$ & $0.0 \pm 0.1$ & $0.0 \pm 0.0$ \\
\hline \multirow[t]{2}{*}{$\mathrm{H}_{2} \mathrm{O}(+)$} & $1.5 \pm 1.0$ & $1.2 \pm 1.1$ & $1.6 \pm 1.8$ & $1.0 \pm 0.6$ & $0.8 \pm 0.7$ & $0.7 \pm 0.9$ \\
\hline & 100.0 & 100.0 & 100.0 & 100.0 & 100.0 & 100.0 \\
\hline$Q$ & - & 0.2 & 1.3 & 7.4 & 26.6 & 26.7 \\
\hline OR & 9.6 & 6.0 & 30.7 & 16.8 & 26.3 & 25.6 \\
\hline$A B$ & 23.3 & 23.2 & 54.3 & 45.4 & 31.8 & 32.8 \\
\hline$A N$ & 23.6 & 22.2 & 2.7 & 7.2 & - & - \\
\hline $\mathrm{NE}$ & 1.4 & - & - & - & - & - \\
\hline $\mathrm{AC}$ & - & - & - & - & 8.8 & 7.3 \\
\hline NS & - & - & - & - & 0.2 & 1.2 \\
\hline $\mathrm{DI}$ & 19.0 & 24.0 & 3.9 & 10.8 & 3. 0 & 3.5 \\
\hline Wo & - & - & 0.6 & - & - & - \\
\hline HY & - & 11.1 & - & 2.9 & 2.7 & 2.5 \\
\hline $\mathrm{OL}$ & 11.6 & - & - & - & - & - \\
\hline $\mathrm{MT}$ & 6.8 & 8. 4 & 5.3 & 6.3 & - & - \\
\hline IL & 4.0 & 4.2 & 1.0 & 2. 3 & 0.6 & 0.4 \\
\hline$A P$ & 0.7 & 0.7 & 0.2 & 0.9 & 0.0 & 0.0 \\
\hline$Q Z$ & -29 & -19 & -9 & +3 & +135 & +132 \\
\hline Femics & 41 & 48 & 10 & 22 & 15 & 14 \\
\hline
\end{tabular}

1P. Average of 60 plateau basalts.

lR. Average of 43 rift basalts.

$2 \mathrm{P}$. Average of 30 plateau intermediates.

$2 R$. Average of 11 rift intermediates.

$3 P$. Average of 42 plateau silicics.

$3 R$. Average of 33 rift silicics. 